WIELKIE TEMATY KULTURY W LITERATURACH SKOWIAŃSKICH

Slavica Wratislaviensia CLXVIII • Wrocław 2019•AUWr No 3875

DOI: 10.19195/0137-1150.168.1

Data przesłania artykułu: 8.09.2017

Data akceptacji artykułu: 19.12.2017

ALICJA Z. NOWAK

Uniwersytet Jagielloński, Polska

\title{
„Czyściec” kontra „podniebne cła” w literaturze polemicznej czasów unii w Brześciu (XVI/XVII metropolia kijowska) - wybrane przykłady
}

Czyściec jest dogmatem Kościoła katolickiego dotyczącym procesu doskonalenia oddzielonej po śmierci od ciała duszy - osiągnął ten status w wyniku prac soboru ferrarsko-florenckiego ${ }^{1}$. Mytarstwa (słowiański: myto), czyli podniebne cła, to jedynie legenda, albowiem Kościół wschodni, apofatyczny i powściągliwy w ustaleniach doktrynalnych, nie miał jasnych ustaleń odnośnie do życia zagrobowego. Mimo to koncepcja powietrznych komór celnych była bardzo rozpowszechniona przede wszystkim dzięki popularnym na Rusi eschatologicznym apokryfom, literaturze hagiograficznej, ascetycznej, a także ikonografii i modlitwom ${ }^{2}$.

W historii stosunków Kościoła wschodniego i zachodniego sprawa czyśćca była dyskutowana przy okazji kolejnych prób przywrócenia jedności. Najpierw w 1274 roku, kiedy to zaakceptowana na drugim soborze w Lyonie nauka o czyśćcu trafiła do wyznania wiary cesarza Michała VIII Paleologa, a przede wszystkim na soborze florenckim, na którym — jak twierdzi John Meyendorff — był to jedyny temat dotyczący eschatologii, który teologowie bizantyńscy zmuszeni

${ }^{1}$ Por. np. K. Strzelecka, Czyściec, [w:] Encyklopedia katolicka, t. 3, red. R. Łukaszyk, L. Bieńkowski, F. Gryglewicz, Lublin 1985, kol. 939-942.

2 R. Mazurkiewicz, Eschatologia Rusi Kijowskiej, [w:] Dzieło chrystianizacji Rusi Kijowskiej i jego konsekwencje w kulturze Europy, red. R. Łużny, Lublin 1988, s. 51-93; A. Z. Nowak, Człowiek wobec wieczności. Ukraińskie i białoruskie prawosławne piśmiennictwo żałobne w XVII w., Kraków 2008, s. 142-152. 
byli zgłębić i usystematyzować. Debata łacinników z grekami wykazała wówczas radykalną różnicę ich perspektyw ${ }^{3}$.

W metropolii kijowskiej rozważania o zagrobowych losach duszy ponownie stały się aktualne $\mathrm{w}$ czasach przygotowań $\mathrm{i}$ bezpośrednio po przeprowadzeniu unii w Brześciu. Pierwsza fala polemiki została wywołana kierowanymi pod adresem Rusinów zarzutami katolickich przedstawicieli obozu kontrreformacyjnego: Piotra Skargi i Benedykta Herbesta. Przedmiotem naszego zainteresowania uczynimy jednak prowadzoną na przełomie XVI/XVII wieku dyskusję z udziałem samych Rusinów (Ukraińców, Białorusinów) osiadłych w Rzeczypospolitej, ponieważ ilustruje ona sposób, w jaki obie koncepcje zaświatów zostały wykorzystane przez reprezentantów wschodniej tradycji kościelnej do przekonywania adwersarzy o własnej słuszności. W toku tej dyskusji wyklarowała się nieco „mglista" dotąd idea mytarstw, była ona bowiem potrzebna przedstawicielom obu stron religijno-wyznaniowego dialogu jako argument potwierdzający istnienie czyśćca bądź przeciwnie — pozwalający na jego odrzucenie.

Jedna z pierwszych definicji czyśćca w polemicznej pracy Rusina została przywołana w dialogu prawosławnego autora z 1603 roku, zatytułowanym Pytania i odpowiedzi (Вопросы и отвъты православному зъ папежникомъ). Zоstała ona włożona w usta papieżnika, czyli łacinnika, i ujęta w formę oskarżenia skierowanego pod adresem prawosławnych:

[...] одшедшимъ душамъ не въруете быти чистцу на очищеніе нькотрыхъ грђховъ, которые мы называемо пургаторіумъ, то естъ чистецъ огненный, въ которомъ души людей христіянскихъ, очищающися повшехныхъ гръховъ, идутъ заразъ, пособляючимъ и намъ за ними насвятшими офьрами и ялмужнами, до неба 4 .

Praca prezentowała także prawosławną wizję pośmiertnych losów duszy. Był to jednak opis skrótowy i nie został w nim użyty termin „mytarstwo”. Charakterystyce podniebnych ceł posłużył krótki fragment z komentarzy Jana Chryzostoma na List świętego Judy Apostoła:

[...] гды душа отъ тьла розлучается и идетъ отселя, и потыкаютъ ее ангелскіе силы добрые и бъсовскіе гуфы превротные, абы, ведле справъ, которыхъ учинила, или злыхъ, или добрыхъ, и на розныхъ мъстцяхъ, или сіи, или овыи посадили еђ, заховуючи ажъ до посльднего дне $[\ldots]^{5}$.

${ }^{3}$ J. Meyendorff, Teologia bizantyjska. Historia i doktryna, przeł. J. Prokopiuk, Warszawa 1984, s. 281-282. Zaproponowaną legalistyczną koncepcję czyśćca ogniowego odrzucił Marek z Efezu; o przebiegu tej dyskusji zob. Дж. Гілл, Флорентійський Собор, Львів-Рим 2016 (pierwsze anglojęzyczne wydanie: Cambridge 1959), s. 128-132. Ci, którzy podpisali dokumenty soborowe, zgodzili się na istnienie czyśćca, lecz nie byli zobowiązani do wiary w fizyczną, ogniową mękę; por. W. Hryniewicz, O soborze florenckim inaczej. Refleksje ekumeniczne, [w:] idem, Kościoły siostrzane — dialog katolicko-prawosławny 1980-1991, Warszawa 1993, s. 302.

${ }^{4}$ Вопросы и отвъты православному зъ папежникомъ, 1603, [w:] Русская Историческая Библіотека, t. 7. Памятники полемической литературы въ Западной Руси, cz. 2, Санктпетербургъ 1882 (dalej: RIB 7), kol. 53-54.

${ }^{5}$ Ibidem, kol. 61. 
Wspomniane w tym objaśnieniu miejsca przebywania dusz są różne w zależności od wartości życia ludzi zmarłych, co oznacza jednocześnie akceptację dla popularyzowanej przez Kościół zachodni idei sądu indywidulanego, wstępnego, zaraz po śmierci. Według wielu prawosławnych polemistów sprawiedliwi przebywają do dnia sądu na łonie Abrahama lub w raju, o których mowa w Ewangelii według świętego Łukasza w przypowieści o bogaczu i ubogim Łazarzu $(16,19-31)$ oraz w historii o Dobrym Łotrze $(23,39-42)$. Grzesznicy są zsyłani do otchłani nazywanej przez Rusinów adem, czyli hadesem. Jak podkreślał między innymi Wasyl Surażski, autor wydrukowanej w Ostrogu tak zwanej Knyżyci $($ О єдиной истинной православной върг, 1588), nigdzie w Biblii nie znajdziemy wzmianki o tym, że dusze powinny się oczyścić z grzechów przed dotarciem na wskazane miejsca wytchnienia:

Нигдъже убо отюдъ въ святыхъ писанихъ не обрьтается, абы по смерти покааніе или очищеніе грђховъ быти мъло, окромъ здъ, дондеже въ тъль пребываемъ. [...] Разбойнику же, паки покаавшуся, висящу на кресть: «днесь съ мною будеши въ раи» глаголеть Христос, а не до чистителаго огня отсылаетъ ${ }^{6}$.

W środowisku prawosławnym pojęcie mytarstwa oraz obszerny opis powietrznych komór celnych, w których demony zatrzymują dusze w celu dręczenia i oskarżania o poszczególne grzechy, pojawił się dopiero w przypisywanej Zachariaszowi Kopysteńskiemu, przyszłemu archimandrycie pieczerskiemu, Księdze o wierze (Книга о втьрь Сдиной, 1621):

[...] душъ по выстю зъ тъла бываютъ турбованы на аерђ, што по-словенску называют воздушныи мытарства душъ, а по-грецку Єнаерїа телонїя тӧн ұйхон, а по-руску мученя, гамованя, пытаня и истезаніа на повътру душъ. БовЊм злыи духове, живучіи на повътру, чинятъ душамъ перепону и перешкоду и гамованіе, зъ аггелами добрыми препираючися и собъ душу привлящаючи. А биваетъ то не на едном мъсци, и не от единого діавола, але от розныхъ и на розныхъ мъсцахъ, и за розныи гръхи. Яко бовъмъ иныи а иныи сутъ до грђховъ розныхъ побужаючіи, яко авва Сиренъ учитъ, такъ тыж и баданя чинятъ не едны. Овъ бовъмъ о нечистось, а овъ за убійство, и онъ за блюзнърство, той за онъ грђхъ, а сей на иный стязуетъ и гамуетъ, такъ власне яко ово видишъ шнуръ онъ маліованый, от пекла початокъ свой маючій, а до неба досягаючій, где и діаволе при грьху каждомъ присьдятъ, яко митници на коморахъ мытничих ${ }^{7}$.

${ }^{6}$ Васил Суразкий (Малюшицкий), О единой истинной православной върғ и о святой соборной апостолской иеркви, Острог 1588, [w:] RIB 7, kol. 845-846; por. też Bonросы и отвътыны..., kol. 61-62.

7 [Захарія Копыстенский], Книга о втрғ Сдиной, Святой, соборной, Апостолской Церкве, которая под розсудок Церкве Всходней поддаєтся, ok. 1619 r., [w:] Архивъ Юго-Западной Россіи, издаваемый Временною Комиссіею для разбора древнихъ актовъ, Высочайше учрежденную при Кіевскомъ, Подольскомъ и Вольнскомъ Генераль-Губернаторг, cz. 1, t. 8. Памятники литературной полемики православныхъ южно-руссовъ съ протестантами и латино-уніатами въ Юго-Западной Руси за XVI и XVII cm., Кіевъ 1887, s. 315-316. Те̨ definicję ceł Zachariasz Kopysteński włączył do rękopiśmiennej Palinodii i kazania żałobnego poświęconego rocznicy śmierci Elizeusza Pleteneckiego (Kijów 1625). 
Komentarz autora dotyczący „,sznura malowanego, który od piekła swój początek bierze i do nieba sięga", przekonuje, że ten obraz, korespondujący z wyobrażeniami ceł z piśmiennictwa czasów średniowiecza, inspirowała ikonografia sądu ostatecznego.

Znamienny jest jednocześnie fakt, że charakterystyczną dla Kościoła wschodniego nazwę i wizję mytarstw w polemice wyznaniowej jako pierwsi przywołali unici. Była ona im szczególnie potrzebna, ponieważ starali się legendy i wyobrażenia o losach duszy po śmierci wykorzystać jako argument w dyskusji na temat istnienia trzeciego miejsca w zaświatach, przeznaczonego dla dusz ludzi nie całkiem złych, ale też nie idealnych. Podniebne cła znajdujące się w sferze wierzeń wyznawców Kościoła wschodniego pozwalały im zatem przybliżyć istotę doktryny o czyśćcu tej propagowanej przez łacinników.

Hipacy Pociej w pracy Unia Greków z Kościołem rzymskim z 1595 roku poświęcił temu problemowi osobny rozdział, zatytułowany $O$ чисиу, о который се тежъ наши спречають, насльдуючы въ томъ всихъ геретыковъ и иновгриовъ, которые твердять, ижь чистиа нъть, а затымъ и памети, и молитвы, и прыноменія за умерлыхъ быти порожніе повъдають ${ }^{8}$. Ten obszerny, oskarżycielski tytuł wskazywał na błędy prawosławnych, którzy odrzucając koncepcję czyśćca, mieli niebezpiecznie zbliżać się poglądami do heretyków i innowierców podważających sens modlitwy za zmarłych ${ }^{9}$. Według polemisty potrzeba wstawiennictwa wynikała $\mathrm{z}$ faktu istnienia trzeciego, obok nieba i piekła, miejsca w zaświatach, w którym zatrzymywana jest większość dusz oczekujących pomocy:

Але ижъ се молимо за усопшихъ, и жертвы за нихъ приносимо, и памети имъ творимъ, муситъ быти, яко есть иншое мъсьце третее, межы небомъ и пекломъ, гдъ бывають душы задержываны, ажъ бы заплатили до наменшого квадранта. А то посполите по нашому зовуть - мытарства ${ }^{10}$.

Dwa lata później ten sam autor w dziele Antirresis (1599), które było odpowiedzią na słynną pracę Apokrisis (wydaną w latach 1597, 1598-1599) ${ }^{11}$, pytał prawosławnych, dlaczego nie wierzą w istnienie czyśćca, skoro ,za umarłe modlitwy czynią, pamięci sprawują i ofiarę świętą przynoszą"12. Wykorzystany argument został następnie podchwycony przez innych uczestników religijnej dyskusji, którzy potrzebę istnienia miejsca odrębnego w świecie pozagrobowym chętnie

${ }^{8}$ Нірасу Росіеј, Унія алъбо выкладъ преднейшыхъ арътыкуловъ ку зъєдноченью Грековъ съ костеломъ Рымскимъ належащыхъ, Вілно 1595, [w:] RIB 7, s. 129-130.

${ }^{9} \mathrm{Na}$ ten temat por. Списаніе против - люторовъ въ двухъ редакиіяхъ, [w:] Русская Историческая Библіотека, t. 19. Памятники полемической литературы въ Западной Руси, cz. 3, Петербургъ 1903 (dalej: RIB 19), kol. 113-138.

${ }^{10}$ Нiрасу Росіеј, Унія алъбо выкладъ..., kol. 130.

11 Prawdziwa tożsamość autora pracy, protestanta Marcina Broniewskiego, piszącego pod pseudonimem Christopfor Philalet, została ujawniona przez jego adwersarzy.

12 Por. Antirresis, abo apologija przeciwko Krzysztofowi Philaletowi, oprac. J. Byliński, J. Długosz, Wrocław 1997, s. 129. 
uzasadniali podzielaną przez katolików i prawosławnych wiarą w skuteczność ofiar, modlitw i innych wstawienniczych wysiłków czynionych w intencji dusz osób zmarłych.

Przykładem może posłużyć wydany w 1625 roku w Krakowie Traktat o duszy Kasjana Sakowicza. Autor opisując pozagrobowe miejsca przebywania dusz, osobne podrozdziały pracy poświęcił kolejno: niebu, mytarstwom i piekłu ${ }^{13}$. Twierdził, że pierwsze miejsce jest przeznaczone dla tych, którzy okazali się zwycięzcami duchowego boju na ziemi, drugie zaś dla tych, którzy wprawdzie walczyli, ale nie zawsze byli mężni i dlatego niektóre potyczki przegrali. Mimo upadków opuszczali oni jednak ten świat, wyraziwszy skruchę i z żalem za grzechy w sercu, dlatego będą mieli możliwość odpłaty za nieodpokutowane winy w czasie wędrówki po cłach $^{14}$. W rozdziale $O$ mytarstwie drugiem miejscu po $s_{\text {mierci }}{ }^{15}$ omawianej pracy Sakowicz pisał, że purgatorium, które Polacy nazywają „czystcem”, a Słowianie „mytarstwami”, niewątpliwie istnieje:

[...] ми вже тому повинні були б визнати це третє місце, що ми молимося за померлих, приносимо за них офіри, відправляємо літургії і навіть маємо для цієї мети, дві суботи щорічно - перед святками і перед м'ясопустною неділею. I оскільки ми чинимо за померлих молитви, літургїі і обідні, особливо восени, то я питаю, за яких? [...] Отже, мусить бути третє місце, в якому душі затримуються тимчасово і після наших молитв і пожертвувань тут, на землі, з нього виходять. Назви це місце як хочеш, „бе” чи „ме”, але передусім визнай, що воно $\epsilon^{16}$.

Takież utożsamienie ceł i czyśćca znajdujemy między innymi w pracy Przyczyny porzucenia disuniey przezacnemu narodowi ruskiemu podane Teodora Skuminowicza-Tyszkiewicza, wydanej w Wilnie w 1643 roku ${ }^{17}$, i w wielu późniejszych, nie tylko polemicznych i unickich, dziełach XVII-XVIII wieku ${ }^{18}$.

Prawosławni wierzą, że modlitwy wznoszone za zmarłych mają moc sprawczą, mogą w sposób znaczący wpłynąć na los duszy w dniu sądu ostatecznego. Dlatego, jak pisał autor Pytań i odpowiedzi, proszą Boga o odpuszczenie drobnych grzechów zmarłego i miłosierdzie dla duszy: „Для тогож за умершими

${ }^{13}$ Korzystam ze współczesnego tłumaczenia na język ukraiński; por. Tрактаm про душy, написаний отием Касіяном Саковичем, ченцем грецької релігї̈, [w:] Пам'ятки братських шкіл на Україні кінець XVI-початок XVII ст. Тексти і дослідження, red. В. І. Шинкарук, В. М. Нічик, А. Д. Сухов, Київ 1988, s. 494-505.

14 Ibidem, s. 495.

15 Tytuł oryginału podaję za J. D. Wagilewicz, Pisarze polscy Rusini wraz z dodatkiem pisarze łacińscy Rusini, oprac. R. Radyszewskyj, Przemyśl 1996, s. 200.

16 [Kasjan Sakowicz], Tрактат про душу..., s. 501.

17 Por. J. D. Wagilewicz, Pisarze polscy Rusini..., s. 216-217.

18 Zdaniem Lilii Bereżnej tendencja do porównywania, a często zbliżania koncepcji czyśćca i mytarstw była zauważalna $\mathrm{w}$ prawosławnym, monasterskim piśmiennictwie do połowy XVIII wieku; por. Л. Бережна, Третіе мғсто удержаніе истяжателное". Ідея митарств у творах Йоаникія Галатовського та украӥнських православних синодиках, [w:] Україна XVII століття: суспільство, філософія, культура, red. і орrac. Л. Довга, Н. Яковенко, Київ 2005, s. 267-280. 
молимося и милостиню чинимо, ижъ еще и малыхъ грђховъ не сужено, абы тымъ передъ декретомъ судію ублагати [...]”19.

To uzasadnienie nie przeczyło przekonaniom katolików, natomiast w obu wymienionych unickich traktatach z 1595 i 1625 roku została wskazana taka cecha czyśćcowej męki dusz, której Kościół wschodni nie zaakceptował. Była to głoszona przez łacinników konieczność odpłaty, czyli „zwrotu ostatniego grosza” (Mt 5, 26) za uczynione w życiu doczesnym zło. Pisał o tym warunku także autor Harmonii z 1608 roku:

A za jakież dusze Kościół Boży i ojcowie każą się modlić — niech powiedzą? Pewnie za tych, którzy są na tym to mytarstwie zatrzymane, o których Pan sam mówi: nie wynidzie, aż zapłaci do najmniejszego kwadrantu ${ }^{20}$.

Chrześcijański Wschód nie wierzył w możliwość osobistej pokuty po śmierci, odrzucono koncepcję zadośćuczynienia Anzelma z Canterbury (ojca scholastycyzmu XI/XII wieku), który przewidywał konieczność odpłaty Bogu za grzechy proporcjonalnie do winy. W historii teologii prawosławnej można odnaleźć różne poglądy na istotę czyśćca, ale niemal wszystkie wypowiedzi są zgodne co do odrzucania sądu o karze i cierpieniu zadośćuczyniającym ${ }^{21}$.

Kolejnym kontrowersyjnym dla prawosławnych tematem, wiążącym się z ideą pośmiertnego zadośćuczynienia, była istota ognia czyśćcowego. Dyskutowano nad nią już w trakcie obrad soboru florenckiego, kiedy to przedstawiciele Kościoła wschodniego zostali zwolnieni z obowiązku wiary w jego materialność, aczkolwiek literatura polemiczna przełomu XVI/XVII wieku dowodzi, że półtora stulecia później problem był nadal aktualny. Autor Harmonii o tym dogmacie pisał:

Kościół Rzymski wierzy y wyznawa, że jest czyściec, i jest własny ogień materialny, w którym się dusze czyszczą, tych zwłaszcza, którzy w pokucie s tego świata zeszli, ale dosyć uczynić za grzechy swoje, jako im było zapowiedziano, przez zejście prędkie s tego świata nie mogli 22 .

Poszukując biblijnego uzasadnienia dla idei oczyszczającego ognia, katoliccy polemiści od najdawniejszych czasów najczęściej wskazywali fragment Pierwszego Listu świętego Pawła do Koryntian (1 Kor 3, 14-15) 23. „Ten, którego dzieło wzniesione na fundamencie, przetrwa, otrzyma zapłatę; ten zaś, którego dzieło spłonie,

19 Вопросы и отвътыны..., kol. 58.

${ }^{20}$ [Hipacy Pociej], Harmonia albo concordantia wiary, sakramentów u ceremoniej cerkwi ś. Orientalnej z kościołem rzymskim, Wilno 1608, [w:] RIB 7, kol. 186. Por. także słowa papieżnika uzasadniające istnienie czyśćca tym fragmentem z Ewangelii Mateusza: „В самомъ Еvангеліи єстъ, гдъ Христосъ напоминаетъ, абы каждый, поки на свътъ живетъ, росправился конечне зъ суперникомъ своимъ, абовъмъ вверженъ будетъ въ темницу, и не выйдетъ оттолъ, ажъ отдасть посльдній кодранть" - Bonросы и отвъты..., kol. 56.

21 „Człowiekowi umierającemu w łasce Bóg przebacza grzechy, nie wymagając kar ekspiacyjnych, gdyż jedynym przebłaganiem Boga za grzechy świata jest Chrystus" - W. Hryniewicz, Czyściec w teologii prawostawnej, [w:] Encyklopedia..., s. 942-943.

22 Hipacy Pociej, Harmonia albo concordantia wiary..., s. 186.

23 Dyskusja mnichów Atonitów z papieskim legatem — J. Le Goff, Narodziny czyśćca, przeł. K. Kocjan, Warszawa 1997, s. 288-289. 
poniesie szkodę: sam wprawdzie ocaleje, lecz jakby przez ogień" 24 . W omawianym okresie nieco dłuższy passus z tego listu przytoczył autor Pytań i odpowiedzi, wkładając go w usta swego adwersarza papieżnika, który owo biblijne „ocalenie” interpretował jako rezultat przejścia przez tymczasowy ogień czyśćcowy:

И зась апостолъ: „если хто будуетъ на томъ фундаментъ злото, сребро, каменіе дорогое, дрова, сьно, тростіе, каждого робота явна будетъ, абовъмъ день обявитъ, поневажъ огнемъ откривается, и каждого робота, якая естъ, огнь спробуетъ, которое прибудовалъ, заплату возметъ, если которого робота згоритъ, шкоду подиметъ, а самъ збавенъ будетъ", то есть выйдетъ съ того чистцового огня ${ }^{25}$.

O popularności tych wersetów biblijnych świadczą liczne, odpierające katolicką wykładnię, odpowiedzi prawosławnych polemistów. Według nich słowa z apostolskiego listu nie dotyczą ognia tymczasowego, który będzie ratunkiem dla grzeszników, ale odnoszą się do ognia wiecznego i wydarzeń, które nastąpią wraz z nadejściem sądu ostatecznego. A zatem ,ci, którzy ocaleją”, nie będą mieli udziału w nagrodzie niebieskiej, przeciwnie — według polemisty fragment odnosi się do tych, którzy zostaną skazani na wieczny ogień. Wypowiedź prawosławnego uczestnika dialogu została wsparta autorytetem Cyryla Aleksandryjskiego z Kazania o Antychryście oraz objaśnieniami pisma świętego Jana Chryzostoma (IV wiek) i Teofilakta z Ochrydy (XI wiek).

Златоустый на тую епистолію до Коринтовъ пишетъ: „если хто золотую зброю носечи пройдетъ рђку огненную, свђтльйшимъ выходитъ. А если съно, дрова носячи пройдетъ, не толко абы собъ што помогль, але и тое погубитъ што бы мълъ. Тымъ же способомъ и при учинкахъ. Прето (мовитъ) ижъ шкоду подойметъ, а то естъ первая мука, а самъ спасется, але такъ, якъ огнемъ, и ото другая. А што апостоль мовить, такъ то естъ, ижъ зъ учинками не згинетъ, абы не мъль быти, але пребудетъ на въки въ огни ${ }^{26}$.

Wypowiedź wieńczy dobitne stwierdzenie, że ogień tymczasowy nie istnieje, albowiem zapowiedziany w Biblii ogień strawi świat w dzień sądu, a grzesznicy zostaną wówczas poddani niemającej końca męce:

Прето немаш мукъ и огня дочасного, ани души безъ тьла скоро по смерти полеруючого, кгдыжъ въ денъ судный тотъ же огнь, которого справедливые пройдутъ, грђшныхъ (по декретъ страшномъ, кгды речетъ: идъте от мене, не заню васъ) зъ собою загорнеть и на въки въчные мучити будетъ 27.

Według Melecjusza Smotryckiego, który w pierwszym okresie swojej polemicznej aktywności optował za poprawnością biblijnych komentarzy Jana Chryzostoma, list apostolski egzemplifikujący naturę ognia wiecznego został przez

24 Biblia Tysiaclecia, wyd. 3 popr., Poznań-Warszawa 1995, s. 1294. Komentarz do tego fragmentu por. J. Buxakowski, Wieczność i człowiek. Eschatologia, „Teologia Prawd Wiary”, t. 8, Pelplin 2001, s. 234-235.

25 Вопросы и отвътын..., kol. 56.

${ }^{26}$ Ibidem, kol. 57.

27 Ibidem, kol. 58. 
katolików błędnie odczytany ${ }^{28}$, co autor Trenosu (1610) spisał na poczet słabej znajomości języka greckiego wśród łacinników:

Przywodzicie na świadectwo błogosławionego Augustyna albo inszego kogo z Rzymskich tego wieku Doktorów, którzy inaczej te Pawłowe słowa rozumieli, a miejsca Tego miasto fundamentu Czyścowego ognia używali. Którym tak odpowiadamy. Jeśli słuszna rzecz jest aby Greckie pism Grekowie wykładali, gdyż przeciw temu niemasz co rzec, iż Grekowie lepiej pospolity swój język umieją z przyrodzenia aniż ludzie inszej nacjej z nauki, ponieważ tedy po Grecku Apostoł pisał, nikt zaiste z Łacinników tego miejsca własniej wyrozumieć i przystojniej wyłożyć niemógł nad Chryzostoma świętego, dla czego słusznie na owych, których jest w więcej sententia przyzwolić, a niźli na Łacińskich Doktorów zdanie [...] $]^{29}$.

Prawosławni, broniąc się przed uznaniem idei kary ekspiacyjnej w czyśćcu, najczęściej powoływali się na pochodzącą z Ewangelii według świętego Mateusza przypowieść o pannach mądrych i głupich (25, 1-13). Sięgnęli po ten fragment Biblii między innymi autor Pytań $i$ odpowiedzi $i^{30}$, autor Księgi o wierze oraz Iwan Wyszeński, zadając katolikom pytanie o przyczynę bezwzględnego odrzucenia panien, które pozostawało w sprzeczności z przekonaniem o możliwości samodzielnego naprawienia zaniedbań:

\begin{tabular}{|c|c|}
\hline Zachariasz Kopysteński & Iwan Wyszeński \\
\hline $\begin{array}{l}\text { До того, што еще речемо о оныхъ пятихъ } \\
\text { глупыхъ паннахъ, чому до облюбенца не } \\
\text { приступаютъ очистившися огнемъ? Чему } \\
\text { не отсылаетъ ихъ очиститися поломенем } \\
\text { огненым и такъ войти до ложници, але рече- } \\
\text { но им: „не знаю васъ”, и не пущаетъ ихъ до } \\
\text { себе, але преч отсылаетъ? }\end{array}$ & 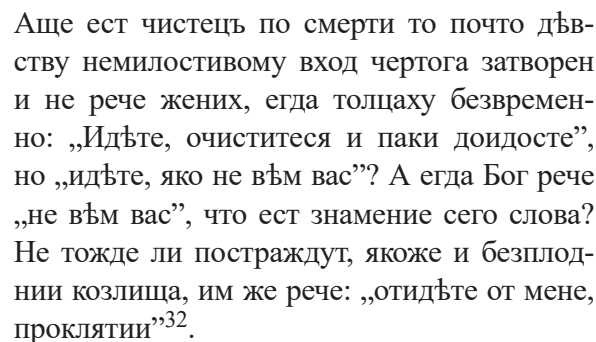 \\
\hline
\end{tabular}

Prawosławni nie akceptowali zatem idei ekspiacji, odrzucali także tezę o fizyczności oczyszczającego cierpienia. W Księdze o wierze argument z obszaru logiki wskazywał na bezsens twierdzenia o męce fizycznej, której miała zostać poddana niematerialna, gdyż rozłączona z ciałem, dusza ${ }^{33}$. Ponadto wedle przy-

${ }^{28}$ Sześć różnych interpretacji wspomnianego fragmentu z listu Pawła do Koryntian powstałych na przestrzeni dziejów podaje A. Jankowski; zob. Z. J. Kijas OFMConv, Odpowiedzi na 101 pytań o rzeczy ostateczne, Kraków 2004, s. 82-84.

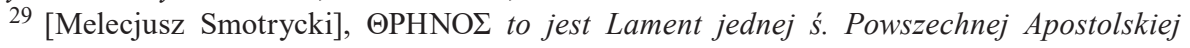
Wschodniej Cerkwie z objaśnieniem Dogmat Wiary przez Theophila Orthologa tejże świętej wschodniej Cerkwie Syna, Wilno 1610, reed., [w:] Collected Works of Meletij Smotryc`kyj, wstęp D. A. Frick, „Harvard Library of Early Ukrainian Literature. Texts”, t. 1, Cambridge 1987, s. 175.

30 Bопросы и отвъвты..., kol. 54.

31 [Захарія Копыстенский], Книга о вторт..., s. 314-515.

32 Йоанна мниха извъщение краткое о латинских прелестех, о заблуждении от пути истиннаго и болезнех смертоноснаго мудрования, [w:] И. Вишенский, Сочинения, red. И. П. Еремин, Москва-Ленинград 1955, s. 115.

33 [Захарія Копыстенский], Книга о върть..., s. 314. 
woływanych opinii Ojców Kościoła grzech został popełniony przez człowieka stanowiącego jedność psychofizyczną i w takiej też postaci będzie on karany: „Іоан Дамаскинъ во книгахъ четвертыхъ пишетъ: »душа ани добра, ани зла тутъ безъ тъла не могла чинити, едно посполу, претожъ обое вкупъ заплату приймутъ «"34.

Sakowicz znalazł odpowiedni kontrargument na te twierdzenia. Tłumaczył bowiem, że rzecz, która może się wydać niemożliwa z ziemskiego punktu widzenia, dla wszechmogącego Boga już taka nie jest, czego dowodzi przenikanie materii, czyli święconej wody, w niematerialną duszę w trakcie chrztu oraz cechująca ją moc usuwania pierworodnego grzechu:

[...] деякі звикли думати, що душа без тظла не може терпіти жодних мук, бо, кажуть вони, як матеріальний вогонь може палити нематеріальну душу, коли це річ протилежна? Але я тебе запитаю, як з твоїм матеріальним тілом поєднана твоя нематеріальна душа, з ним живе, веселится і сумує? Або як матеріальна річ - вода — проникає при хрещенні в нематеріальну річ — душу і нематеріальну річ — першородний гріх — 3 неї вмиває. Скажеш, те здійснюєтся через дію Божої сили і ласки, невидима божественна ласка через видимий знак елементарної води торкається душі й очищує ії̈ від гріха. I якщо це може бути там, то чому ж не може бути й тут, тобто чому вогонь як засіб божественної справедливості не може цією ж Божою силою мучити душу, як він мучить безтілесних дияволів ${ }^{35}$.

Na podstawie tekstu popularnej modlitwy za zmarłych Sakowicz wnosił nawet o rodzaju męki, której poddawane są dusze przebywające na mytarstwach, w pełni utożsamionych przez niego z czyśćcem. Wśród zanoszonych bowiem przez żywych $\mathrm{w}$ intencji zmarłych próśb znajdują się te o przeniesienie duszy w miejsce jasne, pełne ochłody i ciche, wolne od cierpień, utrapień i trosk ${ }^{36}$ i dlatego według polemisty możemy wierzyć, że przebywają one w ciemnym, niespokojnym i - co istotne - zbyt gorącym otoczeniu, w nieustannej trwodze, smutku i zgryzocie ${ }^{37}$.

Prawosławni odrzucali te ustalenia, a odwołując się do autorytetu Ojców, przekonywali że „na tym świecie się polerujemy uciskami i kłopotami, abowiem tam mękam, a nie czyszczeniu jest czas" 38 .

${ }^{34}$ Вопросы и отвьты..., kol. 57.

35 [Kasjan Sakowicz], Трактат про душу..., s. 504-505.

36 Tekst tej modlitwy por. np. Млітвник или Требник, Стрятинъ 1606, k. 230v.

37 [Kasjan Sakowicz], Трактат про душу..., s. 501-502.

38 Melecjusz Smotrycki, Ammizpaфu albo odpowiedź na skript uszczypliwy, przeciwko ludziom Starożytnej religiej greckiej od apostatów cerkwie wschodniej wydany..., Wilno 1608, [w:] RIB 19, s. 1278. Te słowa, należące do Grzegorza z Nazjanzu, cytowało wielu polemistów: „,[...] жадного чистцового огня, въ которомъбыся теперъ, по розлученюся зъ тъломъ, души самыи без тъла чистити и полеровати мълы, алеся, яко святый Григорій Назіанскій мовитъ, ту на том свђтъ полеруемо утисками и клопотами, абођмъ тамъ мукамъ, а не чищеню часъ есть” - [Захарія Копыстенский], Книга о въғрr..., s. 323-324. Por. także „Григорій Назиянскій на плягу мъста вършъ тринадцатый пишетъ: тут ся полеруемо отъ Бога навъженемъ и бъдами, абовъмъ тамъ мукамъ, а не очищеню часъ, яко Оригенъ брьдитъ”- - Bопросы и отвъъты..., kol. 57. 
W sposób dobitny wypowiedział się na ten temat Iwan Wyszeński, pisząc o „doczesnym purgatorium”, które jest jedynym prawdziwym czyśćcem dla ludzkości dążącej do Boga, i przeciwstawiając go zaświatowej koncepcji łacinników — fałszywych chrześcijan: „ибо наш пуркгаториум, истинных християн, в плоти, у ложных же - по смерти"з9.

Wypowiedzi utrzymane w podobnym tonie można znaleźć także u innych polemistów. Na przykład Surażski zarzucał łacinnikom skłonność do popełniania błędów, a naukę o czyśćcu traktował jako kolejny tego dowód. Dyskredytując ideę męki czyśćcowej, prawosławni wskazywali jako jej twórcę potępionego na soborze w Konstantynopolu Orygenesa. Obszerny rozdział dotyczący czyśćca — „wymysłu Orygenesowego" — znalazł się w wydrukowanym w Ostrogu w 1588 roku dziele Wasyla (Maluszyckiego) Surażskiego w części zatytułowanej O нъакомъ чистию, егоже Римскые имянують пургаторіумъ ${ }^{40}$ oraz w Ekthesis Marcina Broniewskiego (Kraków 1597), który pisał, że jest to

zmyślenie, źle zrozumiany i zmyślony pierwej od rozmaitych tego świata filozofów basnosłowstwem. A potem Orygenem Adamantowiczem śmiele narysowany i ukorzeniony. A na ostatku doskonale w zachodnim Kościele rozszerzony ogień czyśćcowy ${ }^{41}$.

Podobne wypowiedzi znajdziemy także w innych pracach (między innymi Z. Kopysteńskiego, M. Smotryckiego). Większość z nich zawiera również przestrogi dla wiernych, którzy nie powinni łudzić się nadzieją pośmiertnego zadośćuczynienia, czyściec jest bowiem ,szatańskim pomysłem, który został podsunięty ludzkości dla rozleniwienia i dla zguby żyjących»42. Zapewne dlatego w XVII wieku

39 Йоанна мниха извъщение..., s. 118.

40 „Тъмже всяко явђ есть, яко не отъ божественаго писаніа чистець изобрђтается, но отъ человъческыхъ умышленій съставися, пачеже отъ высокомыслнаго Оригена, онъ же прежде потокы ученіа источи, посльдиже, на свое велемудріе уповаа, падеся, хулныя глаголы о Христъ Спасителю нашемъ отригну[лъ]. Сего ради Божіа помощи обнажися, яко отъ идоложрецъ ятъ бысть, не стерпьвши мукъ, верже ливанъ на жертвище, и пожрьть идоломъ. И за сіе слабости ради своея срамляася, не точію человькомъ нечестивымъ, но и самимъ бъсомъ свободитися отъ мукъ глаголетъ, конецъ мукамъ быти блядуще" - Васил Суразкий (Малюшицкий), О единой истинной православной въьрг..., kol. 852. Niemal identyczne sformułowanie por. „О томъ и таковомъ чистцовымъ огню пуркгуючомъ церковъ Христова першая не слыхала, ани тежъ во книгахъ докторовъ святыхъ найдуемо, прето не отъ божественного писма чистецъ таковый душамъ естъ выналђзенъ, але отъ людскихъ вымысловъ, а надто отъ высокооумнаго въ думъ Оригена, который на початку жродля наукъ выступилъ, на-опосль, на свою велемудрость уфаючи, упалъ, блюзнърскіе мовы мовы о Христь Збавителю нашемъ отригнулъ. Для тогожъ и Божое помочи естъ обнажонъ, гды отъ идоложерцовъ пойманъ былъ, не стерпьвши мукъ, вергъ ливанъ на жертвище и далъ хвалу бъсомъ. И той для причины оустыдаючися мовилъ: не толко человђкомъ безбожнымъ, але и самымъ бъсомъ отъ мукъ въчныхъ свободитися повъдаетъ” - Bonpoсbl и Отвътын..., kol. 54-55.

${ }^{41}$ M. Broniewski, Ekthesis abo krótkie zebranie spraw, które się działy na partykularnym, to jest pomiastnym Synodzie w Brześciu Litewskim, oprac. J. Byliński, J. Długosz, Wrocław 1995, s. 63.

42 Bonросы и отвrъmbl..., kol. 55. 
nie tylko polemiści, lecz także autorzy innych dzieł rozumieli potrzebę wskazania i objaśnienia najważniejszych różnic między obiema koncepcjami ${ }^{43}$.

Podsumowując, należy stwierdzić, że wywołany w czasach unii w Brześciu, aczkolwiek nie nowy dla polemiki konfesyjnej, temat czyśćca ${ }^{44}$ skłonił stronę unicką do przywołania wizji podniebnych ceł mających status legendarnego wierzenia. Utożsamienie mytarstw, bliskich wyznawcom Kościoła wschodniego, z koncepcją czyśćca miało oswoić prawosławnych z tą ideą, przekonać nowo przechodzonych na stronę unii wiernych do tej doktryny. Wywołało jednak krytyczną reakcję prawosławnych, skłaniając ich do gruntownego skonfrontowania obu wizji, wykazania zasadniczych różnic, ale i podobieństw, a przede wszystkim do usystematyzowania własnego nauczania dotyczącego trzeciego miejsca w zaświatach. Prawdy wiary miały stać się jasne i zrozumiałe dla wyznawców, ponieważ tylko tak można było ich chronić przed katolicką tezą o tożsamości obu miejsc.

Rozpoczęty przez literaturę polemiczną proces porządkowania eschatologicznych przekonań kontynuowali następnie autorzy literatury kaznodziejskiej i dzieł z obszaru teologii popularnej; znalazł on także odzwierciadlenie w obowiązujących orzeczeniach prawosławnego Kościoła w państwie polsko-litewskim.

\section{Bibliografia}

Antirresis, abo apologija przeciwko Krzysztofowi Philaletowi, oprac. J. Byliński, J. Długosz, Wrocław 1997.

Berezhna L., Tretie město uderzhanie istyazhatelnoe. Ideya mitarstv u tvorakh Ioanikiya Galatovs' kogo ta ukraïn'kikh pravoslavnikh sinodikakh, [w:] Ukraiina XVII stolittya: suspil'stvo, filosofiya, kul'tura, red. i oprac. L. Dovga, N. Yakovenko, Kyi 'v 2005.

Biblia Tysiaclecia, wyd. 3 popr., Poznań-Warszawa 1995.

Broniewski M., Ekthesis abo krótkie zebranie spraw, które się dziaty na partykularnym, to jest pomiastnym Synodzie w Brześciu Litewskim, oprac. J. Byliński, J. Długosz, Wrocław 1995.

Buxakowski J., Wieczność i człowiek. Eschatologia, „Teologia Prawd Wiary”, t. 8, Pelplin 2001. G'ill Dzh., Florentiis 'kii Cobor, L'viv-Rim 2016.

Hryniewicz W., Czyściec w teologii prawosławnej, [w:] Encyklopedia katolicka, t. 3, red. R. Łukaszyk, L. Bieńkowski, F. Gryglewicz, Lublin 1985.

Hryniewicz W., O soborze florenckim inaczej. Refleksje ekumeniczne, [w:] idem, Kościoły siostrzane - dialog katolicko-prawostawny 1980-1991, Warszawa 1993.

Kijas Z. J. OFMConv, Odpowiedzi na 101 pytań o rzeczy ostateczne, Kraków 2004.

Le Goff J., Narodziny czyśćca, przeł. K. Kocjan, Warszawa 1997.

Mazurkiewicz R., Eschatologia Rusi Kijowskiej, [w:] Dzieło chrystianizacji Rusi Kijowskiej i jego konsekwencje w kulturze Europy, red. R. Łużny, Lublin 1988.

${ }^{43}$ W Księdze o wierze o różnicach między cłami (na powietrzu) i czyśćcem (w ogniu) czytamy: „А такъ иное естъ мытарство, а иное огонъ чистителный. И мытарства дъютъся не въ огни, але на повьтру през гамованіе, трудненіе и забороненіе волного пристаня душам. А чистец зась, яко латинници мовят, огонь єстъ, и мучитъ и палитъ душу, а где и на которомъ мъсцу, нехай сами повъдят" - [Захарія Копыстенский], Книга о втрғъ..., s. 316.

${ }^{44}$ Argumenty wysuwane przez ówczesnych polemistów nie były nowe, podobny przebieg miały rozmowy prowadzone w trakcie soboru we Florencji; por. Дж. Гілл, Флорентійський Собор..., s. 271-303. 
Meyendorff J., Teologia bizantyjska. Historia i doktryna, przeł. J. Prokopiuk, Warszawa 1984.

Nowak A. Z., Człowiek wobec wieczności. Ukraińskie i białoruskie prawosławne piśmiennictwo żałobne w XVII w., Kraków 2008.

[Pociej Hipacy], Harmonia albo concordantia wiary, sakramentów i ceremoniej cerkwiśs. Orientalnej z kościotem rzymskim, Wilno 1608, [w:] Russkaya Istoricheskaya Biblioteka, t. 7. Pamyatniki polemicheskoi literatury v" Zapadnoi Rusi, cz. 2, Sankt Petersburg 1882.

Potii Ipatii, Uniya albo vyklad predneishykh artykulov ku zyednochenyu Grekov s kostelom Rymskim nalezhashchykh, Wilno 1595, [w:] Russkaya Istoricheskaya Biblioteka, t. 7. Pamyatniki polemicheskoi literatury v" Zapadnoi Rusi, cz. 2, Sankt Petersburg 1882.

[Sakovych Kasijan], Traktat pro dushu, napysanyj otcem Kasijanom Sakovychem, chencem grec 'koi' religii', [w:] Pam 'jatky brats' kyh shkil na Ukrai'ni kinec'XVI-pochatok XVII st. Teksty i doslidzhennja, red. V. I. Shynkaruk, V. M. Nychyk, A. D. Suhov, Kyi’v 1988.

[Smotrycki Melecjusz], Antigrafi albo odpowiedź na skript uszczypliwy, przeciwko ludziom Starożytnej religiej greckiej od apostatów cerkwie wschodniej wydany..., Wilno 1608, [w:] Russkaya Istoricheskaya Biblioteka, t. 19. Pamyatniki polemicheskoi literatury v" Zapadnoi Rusi, cz. 3, Sankt Peterburg 1903.

[Smotrycki Melecjusz], $\Theta P H N O \Sigma$ to jest Lament jednej ś. Powszechnej Apostolskiej Wschodniej Cerkwie z objaśnieniem Dogmat Wiary przez Theophila Orthologa tejże świętej wschodniej Cerkwie Syna, Wilno 1610, reed., [w:] Collected Works of Meletij Smotryc 'kyj, wstęp D. A. Frick, „Harvard Library of Early Ukrainian Literature”, t. 1. Texts, Cambridge 1987.

Spisanie protiv - lyutorov" v" dvukh" redaktsiyakh", [w:] Russkaya Istoricheskaya Biblioteka, t. 19. Pamyatniki polemicheskoi literatury v" Zapadnoi Rusi, cz. 3, Sankt Petersburg 1903.

Strzelecka K., Czyściec, [w:] Encyklopedia katolicka, t. 3, red. R. Łukaszyk, L. Bieńkowski, F. Gryglewicz, Lublin 1985.

Surazkii (Malyushitskii) V., O edinoi istinnoi pravoslavnoi vrorro i o svyatoi sobornoi apostolskoi tserkvi, Ostrog 1588, [w:] Russkaya Istoricheskaya Biblioteka, t. 7. Pamyatniki polemicheskoi literatury v" Zapadnoi Rusi, cz. 2, Sankt Petersburg 1882.

Voprosy i otvěty pravoslavnomu z" papezhnikom", 1603, [w:] Russkaya Istoricheskaya Biblioteka, t. 7. Pamyatniki polemicheskoi literatury v" Zapadnoi Rusi, cz. 2, Sankt Petersburg 1882.

[Vishenskii Ivan], Ioanna mnikha izvrshchenie kratkoe o latinskikh prelestekh, o zabluzhdenii ot puti istinnago i boleznekh smertonosnago mudrovaniya, [w:] Ivan Vishenskii, Sochineniya, red. I. P. Eremin, Moskva-Leningrad 1955.

Wagilewicz J. D., Pisarze polscy Rusini wraz z dodatkiem pisarze łacińscy Rusini, oprac. R. Radyszewskyj, Przemyśl 1996.

[Zaharija Kopystenskij], Kniga o věrě Edinoj, Svjatoj, sobornoj, Apostolskoj Cerkve, kotoraja pod rozsudok Cerkve Vshodnej poddaetsja, ok. 1619 r., [w:] Arhiv”" Jugo-Zapadnoj Rossii, izdavaemyj Vremennoju Komissieju dlja razbora drevnih" aktov", Vysochajshe uchrezhdennuju pri Kievskom", Podol'skom" i Volynskom" General"-Gubernatorě, cz. 1, t. 8. Pamjatniki literaturnoj polemiki pravoslavnyh" juzhno-russov" s" protestantami i latino-uniatami v" Jugo-Zapadnoj Rusi za XVI i XVII st., Kyi'v 1887. 


\section{"Purgatory" versus "celestial customs duty" in polemic literature of the times of the Union of Brest (Kyivan Metropolitanate): Selected examples}

\section{Summary}

In the Kyiv Metropolitanate, reflections about the afterlife of the soul became important right before and after the Union of Brest. The familiar polemical theme of purgatory returned and the followers of the union with Rome evoked the legendary visions of celestial customs duty (tollgates). The identification of both conceptions was meant to convince and convert the Orthodox to the Catholic doctrine. However, instead it brought about their reaction, prompting them to thoroughly confront both visions, demonstrate the similarities but also fundamental differences, and above all, to systematize their teachings. The polemical process of ordering eschatological beliefs begun in polemic literature and was continued by the authors of sermons, the works of popular theology, and was also reflected in official statements of the Orthodox Church in the Polish-Lithuanian Commonwealth.

Keywords: purgatory, ordeals, soul, polemics, prayer

\section{Чистилище проти митарств у полемічній літературі часів берестейської унії (Київська Митрополія) - вибрані приклади}

\section{Резюме}

Дискусії довкола теми чистилища, що не були новиною уже в конфесійній полеміці, посилилися в часи Берестейської унії та сприяли відродженню серед уніатів легендарної візії піднебесних митарств. Утотожнення митарств із чистилищем стало засобом переконати православних у правильності католицької доктрини, водночас викликало активну реакцію у відповідь. Зіткнення обох концепцій виявило не тільки подібності, але і принципові розходження між ними, спирияло систематизації уявлень та переконань представників кожної зі сторін у питаннях есхатології. Полемічна література започаткували процес формування есхатологічних вірувань, який пізніше продовжили проповідники та автори праць 3 популярного богослов'я, що пізніше було відображено також в офіційних заявах Православної Церкви в Польсько-Литовській державі.

Ключові слова: чистилище, митарства, душа, полеміка, молитва 